\title{
Printing of Linen Fabric for Reduction of Flammability
}

\author{
Aina Bernava \\ Institute of Polymer Materials, Faculty of Materials Science and Applied Chemistry, Riga Technical University
}

\begin{abstract}
Prewashed raw (unbleached) and bleached $100 \%$ linen fabrics were flat screen printed with pastes Tubivis DRL 300 or Tubvinyl 235, a flame retardant agent for cellulosic articles Apyrol CEP addition and pigment Bezaprint Green BT. Half of the printed fabrics were after-washed. The burning characteristics of raw and bleached, and the same printed and printed, after-washed fabrics were tested. The best performance in flame retardancy was achieved for bleached linen printed with Tubivis DRL 300 paste and for after-washed raw linen fabric printed with both pastes.
\end{abstract}

Keywords - Linen fabric, printing, flammability reduction.

\section{INTRODUCTION}

Linen fabrics are popular as home textiles. Nevertheless linen fabrics are flammable. Reduction of flammability of textiles has been increased by governmental legislations in different countries (1). Human safety issues play a leading role in the mainstream world security, ensuring the prevention of accidents that can cause injuries to human health (2), environment and possessions.

Standards used in Latvia for determination of burning behavior of industrial and technical textiles are LVS EN 1624:2001, LVS EN 1625:2001, for determination of ease of ignition of textile fabrics - LVS EN ISO 6940:2001, LVS EN ISO 6940:2004 and LVS EN ISO 6941:2004, for measurement of flame spread for curtains and drapes LVS EN 13772:2003, LVS EN 13772:2011, for protective clothing - LVS EN ISO 15025:2003 (3).

The use of flame retardants (FR) is a one of the most common strategies used to improve the fire performance of textiles and other materials (4).

The global market for FR chemicals is valued at 6.1 million USD in 2014 and is expected to reach 14.32 million USD by 2022 at a compound annual growth rate (CAGR) of $11.25 \%$. Factors that drive the market include a high demand from current and emerging applications, emerging economies and advancement in technology. Increasing costs and strong government regulations are the major restraints of the market. Construction and automotive industry and other major end-user industries of FR chemicals rise globally (5).

In our previous research continuous coating with commercial printing pastes containing antimony trioxide for improving flame retardancy of local Latvian linen fabrics was used. For all coated and coated after-washed fabrics good flame resistance was observed (6).

The use of printing technologies for treatment of textiles allows reaching different effects on inexpensive textile surfaces. The aim of this research is to investigate burning characteristics of raw and bleached linen fabrics, same as in previous research (6), printed with compositions containing commercial pastes Tubivis DRL 300 or Tubvinyl 235, a permanent organophosphate flame retardant agent for cellulosic articles of protective workwear, decoration articles, upholstery fabrics, bed clothes in hospitals, tent fabrics and similar fabrics made in the padding process (7), Apyrol CEP and pigment Bezaprint Green BT (producer CHT BEZEMA). In most of cases flame retardant cellulosics are produced by chemically after-treating fabrics in the textile finishing process that, depending on chemical characteristics and cost, yield flame retardant properties. In cases of correct treatment, textiles finished with Apyrol CEP are stable during multiple washings and dry cleaning (8).

The printing for flammability reducing is applicable for home textiles: curtains, blinds, upholsteries, coverings and wallpapers, airplane and automotive textiles: cars seats, floor carpets etc. (9).

Textile materials are printed using different patterns (raised printing, lowered printing, screen printing) and different techniques (block, roller, flat screen, rotation screen, sublimation) (10).

Colour pigments have been used for printing of textiles for many centuries. They were passed onto the fabric using natural resin. Nowadays, pigment printing market shared of more $50 \%$. Advantage of the technique is cost-effectiveness and the ecological aspect, because the procedure involves no wet processes (11). In pigment printing, water-insoluble pigments are applied with a heat-curable binder system, followed by drying and curing and the physical properties of the pigment print depend greatly upon the adhesive properties of print binder system (12).

In addition to obtaining decorative pattern on a linen textile by printing, it is also possible to improve the fire resistance.

\section{MATERIALS AND METHODS}

\section{A. Materials}

Plain weave raw (unbleached) $100 \%$ linen fabric with surface density $178 \mathrm{~g} \cdot \mathrm{m}^{-2}$ (R0 - Fig. 1 A) and bleached linen fabric with surface density $190 \mathrm{~g} \cdot \mathrm{m}^{-2}$ (B0 - Fig. $1 \mathrm{~B}$ ) from Larelini Ltd. was used. Raw and bleached linen fabrics were pre-washed before printing in a water solution of washing agent Felosan NOF (CHT R Beitlich $\mathrm{GmbH})$, concentration $2 \mathrm{~g} \cdot \mathrm{L}^{-1}$, liquor ratio $(\mathrm{M})-30$, temperature $-100^{\circ} \mathrm{C}$, time $-60 \mathrm{~min}$ with following rinsing in cold/warm water. 


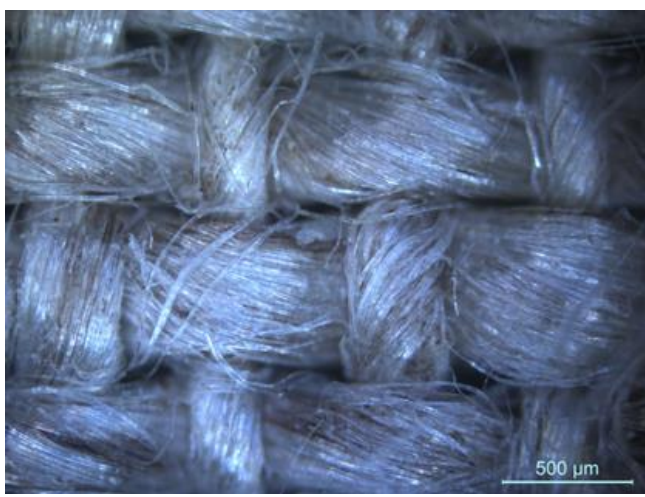

A

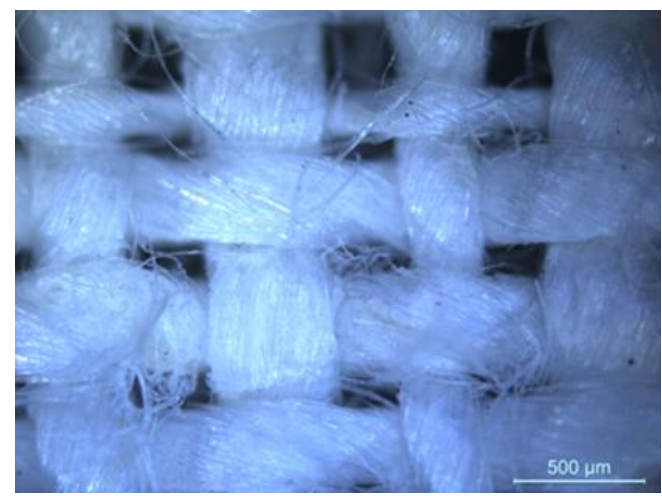

B

Fig. 1. A-R0, B - B0, magnification 50×.

TABLE I

DESIGNATION OF SAMPLES

\begin{tabular}{|c|c|c|c|}
\hline Designation & $\begin{array}{l}\text { Pre- } \\
\text { washing }\end{array}$ & Printing & $\begin{array}{l}\text { After- } \\
\text { washing }\end{array}$ \\
\hline R0 & - & - & - \\
\hline B0 & - & - & - \\
\hline R-TubivisDRL300 & $\mathrm{x}$ & \multirow{4}{*}{$\begin{array}{l}\text { Tubivis } \\
\text { DRL300 }\end{array}$} & - \\
\hline B-TubivisDRL300 & $\mathrm{x}$ & & - \\
\hline R-TubivisDRL300_W & $\mathrm{x}$ & & $\mathrm{x}$ \\
\hline B-TubivisDRL300_W & $\mathrm{x}$ & & $\mathrm{x}$ \\
\hline R-Tubvinyl235MC & $\mathrm{x}$ & \multirow{4}{*}{$\begin{array}{l}\text { Tubvinyl } \\
235 \mathrm{MC}\end{array}$} & - \\
\hline B-Tubivinyl235MC & $\mathrm{x}$ & & - \\
\hline R-Tubivinyl235MC_W & $\mathrm{x}$ & & $\mathrm{x}$ \\
\hline B-Tubivinyl235MC_W & $\mathrm{x}$ & & $\mathrm{x}$ \\
\hline
\end{tabular}

\section{B. Printing}

Commercial synthetic thickener for pigment printing Tubivis DRL 300 or screen-printable dispersion based adhesive Tubvinyl 235 with addition of permanent organophosphate (chemical composition was not given), flame-retardant for cellulosic textiles Apyrol CEP (stable during multiple washings and dry cleaning) with proportion of chemicals in printing paste (1:2) and pigment Bezaprint Green BT (2 w.t.\% of paste) was mixed manually (producer of all chemicals was CHT BEZEMA).

For all fabrics the same flat screen printing method was used: the print paste was squeezed across the screen mesh onto a substrate using a blade. Drying of printed samples was done at $110-120^{\circ} \mathrm{C}$ for $7 \pm 1 \mathrm{~min}$ and a thermal treatment at $160{ }^{\circ} \mathrm{C}$ for $3 \pm 1$ min was applied.

\section{After-washing.}

For half of the printed raw and bleached linen fabrics 5 washing cycles in solution of sodium carbonate $\left(3 \mathrm{~g} \cdot \mathrm{L}^{-1}\right)$ and washing agent Felosan NOF $\left(5 \mathrm{~g} \cdot \mathrm{L}^{-1}\right)$ in distilled water at $\mathrm{M} \mathrm{30,40}{ }^{\circ} \mathrm{C}$ for $15 \mathrm{~min}$ with following rinse in cold/warm water, according to ISO 105-C10:2006 was used.

\section{Burning Test.}

Each of 6 received samples ( 14 pieces -8 vertically and 6 horizontally, $200 \times 160 \mathrm{~mm}$ ) were tested in accordance to LVS EN ISO 15025:2003 for protective clothing - test for limited flame spread to the surface (horizontal test) and the bottom edge (vertical test) of fabric, before and after 5 washing cycles. The burning tests were done in Latvian Centre of Certification (LATSERT).

\section{RESULTS AND DISCUSSION}

Prewashed raw (Fig. 1 A) and bleached (Fig. 1 B) Latvian linen fabrics were printed manually using the flat screen method. Commercial synthetic thickener Tubivis DRL 300 or dispersion-based adhesive Tubvinyl 235 with permanent organophosphate flame-retardant for cellulosic textiles Apyrol CEP and pigment Bezaprint Green BT were used for printing. The right side of the fabrics was with a decorative print (Fig. 2 A, Fig. 3 A, Fig. 4 A, Fig. 5 A). Pushing on the left side fabrics printed with synthetic thickener Tubivis DRL 300 was slightly noticeable (Fig. 2 A, Fig. 3 A), while pushing of the flock adhesive Tubvinyl 235 was observed vastly through the fabric printing paste (Fig. 4 B, Fig. 5 B).

The changes of the printing quality of samples after 5 washing cycles were not noticeable.

The results of burning test showed (Table II) that the raw and bleached linen fabrics burned completely and formation of thermal degradation product debris was observed. The raw linen printed with Tubivis DRL 300 paste burned completely, while after 5 washing cycles the right side of the raw linen printed with the same paste did not burn, if the horizontal flame applying method was used, but using the other method the fabric burned completely.

The afterglow time of this fabric was $8-10 \mathrm{~s}$. This is $6.4-8.8$ times shorter than for the raw linen without print. Debris was observed.

For bleached linen printed with Tubivis DRL 300 flame did not reach the top of the sample and flame extinction was observed after $12-18 \mathrm{~s}$, but for the same after-washed fabric flame extents after 16-40 s depending on the method of flame application.

The afterglow time of bleached linen fabrics was $1-2 \mathrm{~s}$. This was 40-29 times shorter (B/TubivisDRL300) than for bleached linen without printing and for after-washed fabrics the afterglow time was 80-58 times shorter (B/Tubivis DRL300/W). Debris was not observed. 
TABLE II

RESULTS OF BURNING TESTS OF UNPRINTED AND PRINTED LINEN FABRICS.

\begin{tabular}{|c|c|c|c|c|c|c|c|c|}
\hline 高塄 & $\stackrel{\infty}{\overrightarrow{1}}$ & $\stackrel{m}{\overrightarrow{!}}$ & 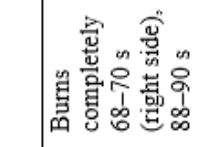 & 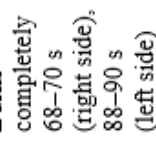 & $\prod_{i}^{n}$ & $\tilde{q}$ & $\stackrel{\mathscr{2}}{\sim}$ & 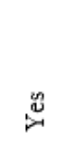 \\
\hline 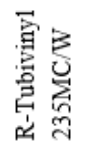 & $\stackrel{n}{\check{\sigma}}$ & 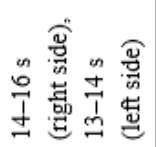 & 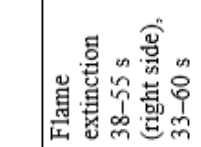 & 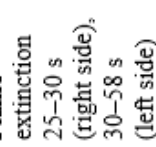 & 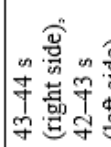 & 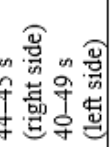 & $\stackrel{\mathscr{N}}{\mathscr{N}}$ & $\mathscr{u}_{\breve{u}}^{\mathscr{u}}$ \\
\hline 裹 & 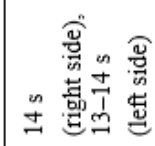 & $\begin{array}{l}\infty \\
\vdots \\
0\end{array}$ & & & 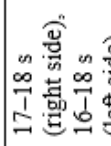 & 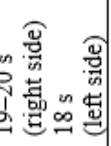 & 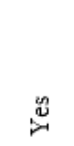 & 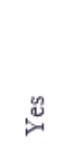 \\
\hline 裹 & $\stackrel{m}{\stackrel{m}{I}}$ & 离 & & & 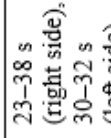 & 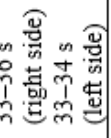 & 唯 & 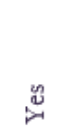 \\
\hline 䇾亳 & $\stackrel{n}{=}$ & 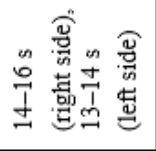 & & & $\stackrel{m}{\rightarrow}$ & $\stackrel{m}{\rightarrow}$ & ґ̊ & ஃ \\
\hline 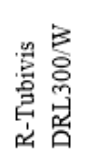 & 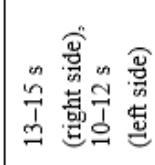 & $a_{a}^{n}$ & 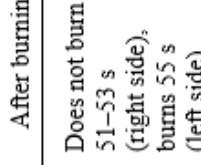 & & 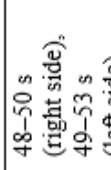 & 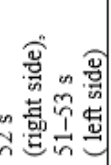 & 总 & 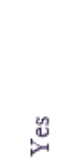 \\
\hline 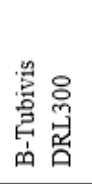 & 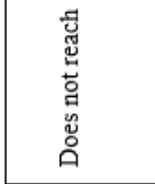 & 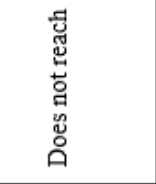 & & & $\stackrel{n}{N}$ & $\stackrel{n}{N}$ & 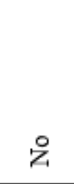 & 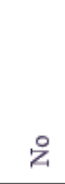 \\
\hline 总。 & $\stackrel{n}{\underline{m}}$ & $\frac{1}{1}$ & & & 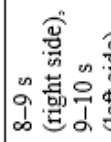 & 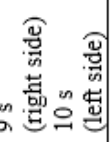 & 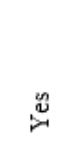 & $\mathscr{U}$ \\
\hline 间 & $\overrightarrow{\vec{\omega}}$ & $\dot{a}$ & 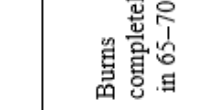 & 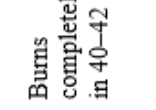 & 点 & 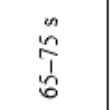 & 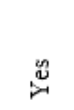 & 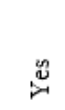 \\
\hline \% & $\dot{\omega}$ & $\dot{b}$ & 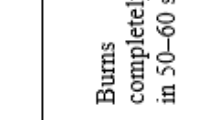 & 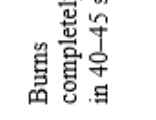 & 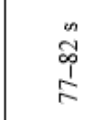 & 号 & $\stackrel{\mathscr{\omega}}{\varkappa}$ & 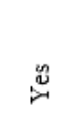 \\
\hline 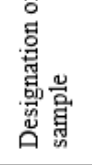 & 嚆 & 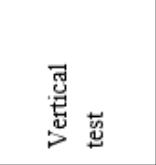 & 总 & 哥 & 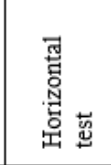 & $\begin{array}{l}\text { 焉 } \\
\text { : }\end{array}$ & 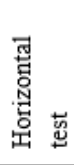 & 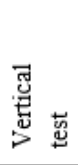 \\
\hline
\end{tabular}


The afterglow time of the bleached linen fabrics (B/TubivisDRL300) was 40-29 times shorter than for bleached linen without print and for after-washed fabrics (B/Tubivis DRL300/W) it 80-58 times shorter. Debris not observed for tested samples. For bleached linen printed with Tubivis DRL 300 no ignition was observed, as measured by the standard EN 1101; this corresponds to 3 class of textile fire resistance (3).

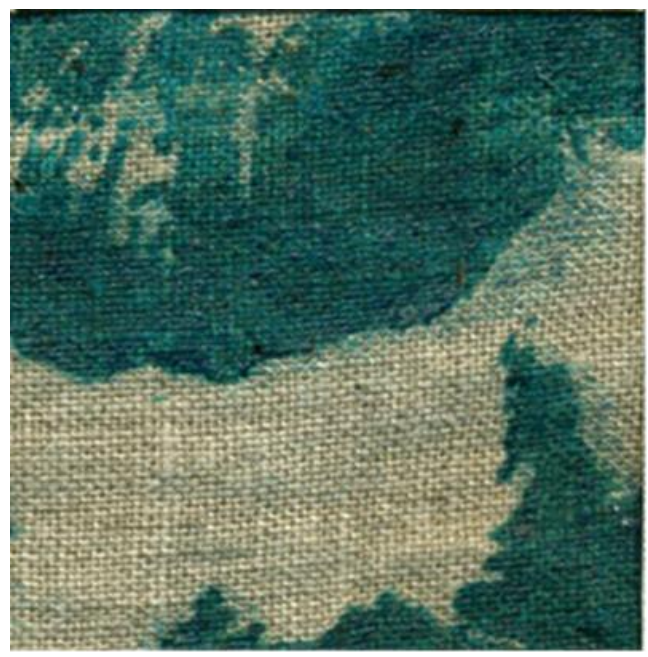

A

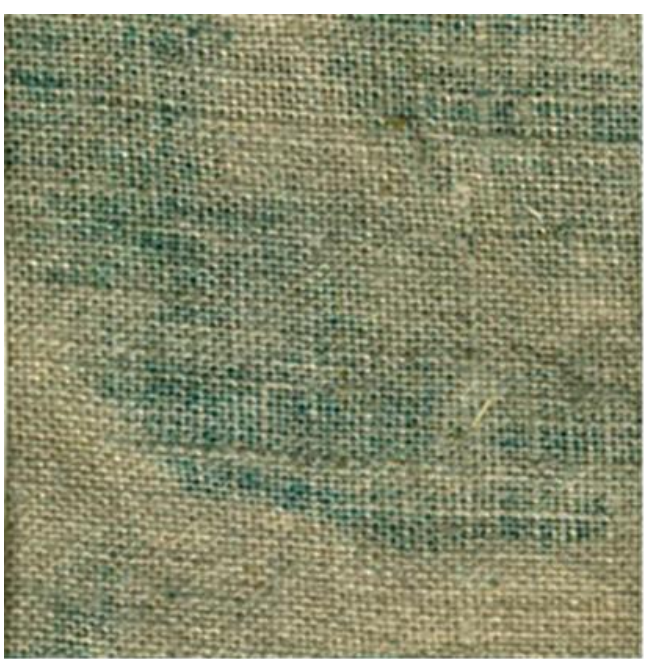

B

Fig. 2. Printed raw linen (A - right side, B - left side) with flameretardant Apyrol CEP and commercial paste Tubivis DRL 300.

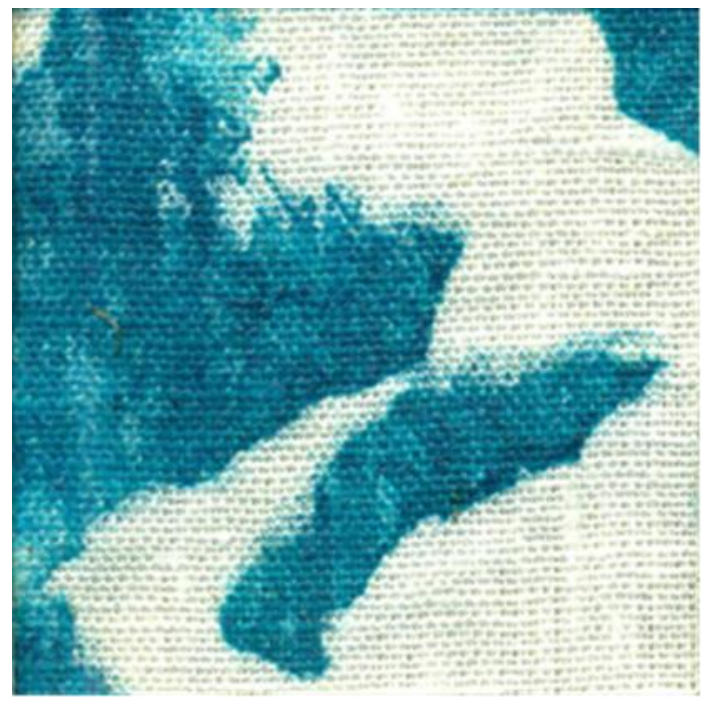

A
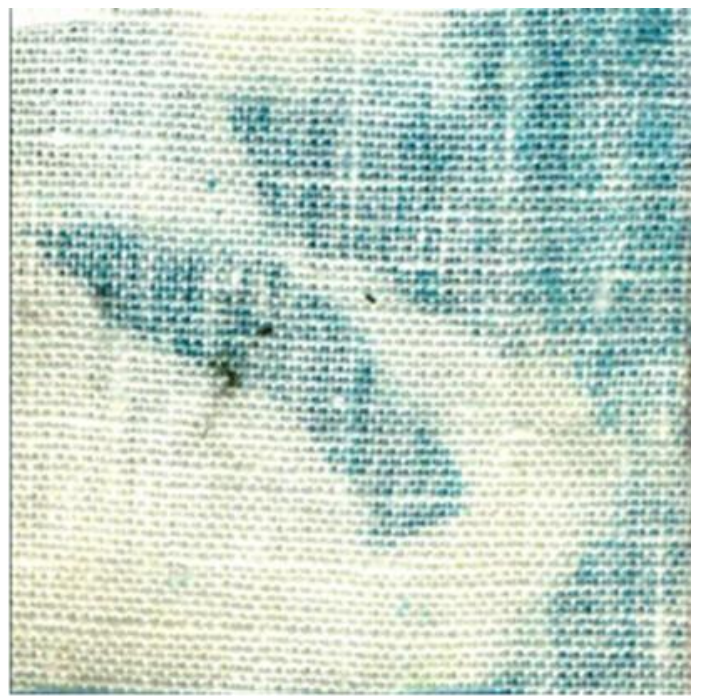

Fig. 3. Printed bleached linen (A - right side, B - left side) with

flame-retardant Apyrol CEP and commercial paste Tubivis DRL 300.

Raw linen fabrics printed with Tubvilyl 235 MC burned completely, but the burning time was 1.4 times longer, while the afterglow time was 2.7-1.8 times shorter than for raw unprinted linen fabric. Flame extinction was observed for the same fabric after 5 washing cycles, afterglow time was $\sim 1.2$ times longer than for printed raw linen and $\sim 2.2$ times shorter than for raw linen. For raw linen fabrics printed with Tubvilyl 235 MC paste formation of debris was observed. 


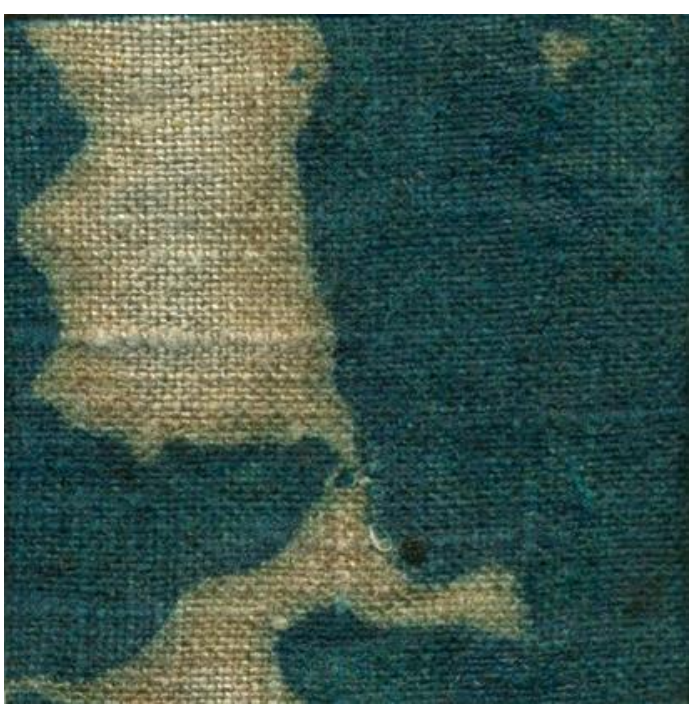

A

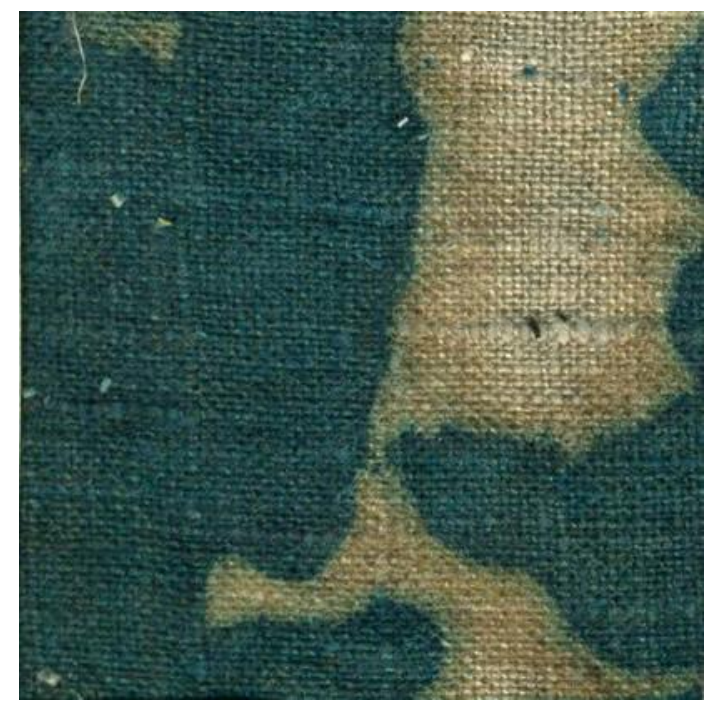

B

Fig. 4. Printed raw linen (A - right side, B - left side) with flameretardant Apyrol CEP and commercial paste Tubvinyl 235 MC.

Bleached linen fabrics printed with Tubvilyl 235 MC burned completely, but burning time was 1.1-1.3 times longer and afterglow time was 4.6-3.9 times shorter than for bleached linen without printing. The burning time for the same fabric after 5 washing cycles was $\sim 1.1$ times shorter using the horizontal method of flame application and 1.3 times longer using vertical method. Afterglow time for after-washed fabric was 9-7 times shorter than for printed fabric. Formation of debris was observed for the bleached linen fabric printed with Tubvilyl 235 MC paste.

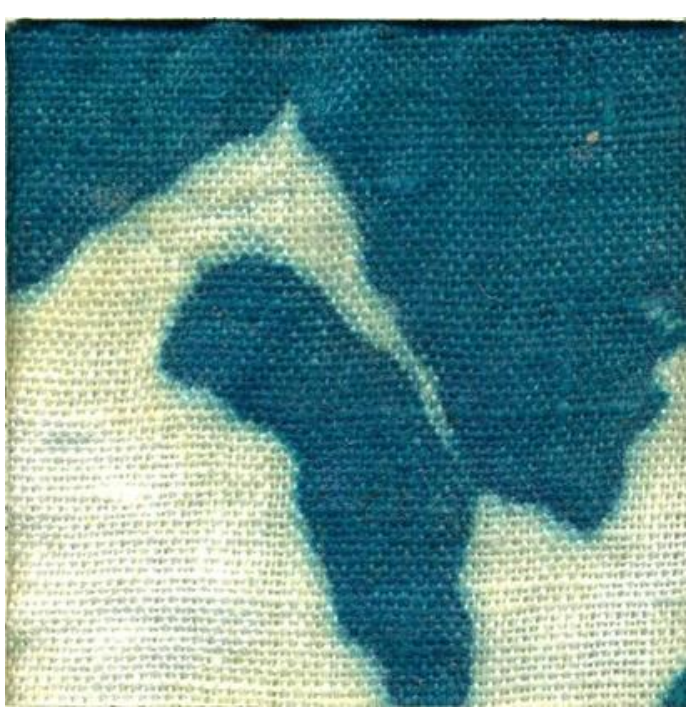

A

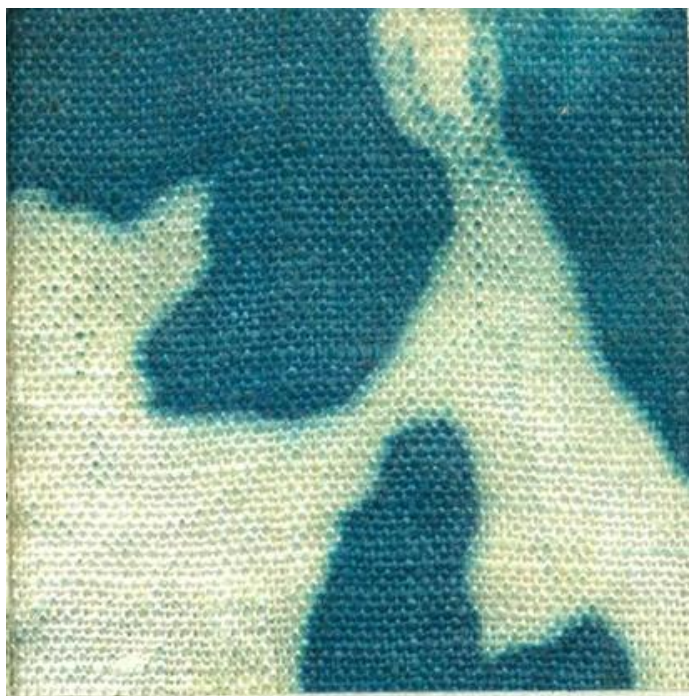

Fig. 5. Printed bleached linen (A - right side, B - left side) with flameretardant Apyrol CEP and commercial paste Tubvinyl $235 \mathrm{MC}$.

\section{CONCLUSION}

A decorative pattern with flat screen method and a reduction of flammability of local linen fabrics was achieved with addition of organophosphate flame-retardant Apyrol CEP, commercial paste Tubivis DRL 300 or Tubvinyl 235 and pigment Bezaprint Green BT.

The best improvement of flame retardancy - flame extinction and reduction of afterglow time for bleached linen printed using Tubivis DRL 300 printing paste - 40-29 times and 80-58 times for after-washed fabric was achieved in comparison to unprinted bleached linen.

For raw linen printed using both pastes the best results were observed after 5 washing cycles, compared to printed raw linen fabrics: for Tubivis DRL 300 printing paste reduction of afterglow time was 6.4-8.8 times shorter. With Tubivinyl 235 MC paste it was 2.7-1.8 times shorter compared to unprinted raw linen.

The formation of debris or non-combustible products were observed for fabrics printed with both pastes, except for bleached linen printed with Tubivis DRL 300. 


\section{ACKNOWLEDGMENT}

The author would like to thank Professor, S. Reihmane from Riga Technical University for the support in the research.

\section{REFERENCES}

1. Mostashari, S.M., Mostashari, S.Z. Thermogravimetrique Analysis of a Cotton Fabric Incorporated by Graham's Salt Applied as a Flame Retardant, Journal of Thermal Analysis and Calorimetry, 2009, vol. 95, no. 1, pp. 187-192. http://dx.doi.org/10.1007/s10973-008-9088-x

2. Borisova, A., Reihmane, S. Flame Retardant Cellulosic Textiles, Tekstilna Industrija, 2012, vol. 3, pp. 5-12.

3. Latvijas standarts" (LVS). Available from: https://www.lvs.lv/lv, [viewed 20. 11.2015].

4. Hirschler, M. M., Safety, health and environmental aspects of flame retardants, Handbook of Fire Resistant Textiles, Ed. by: Kilinc F.S. Woodhead Publishing Series in Textiles, 2013, pp. 108-114. http://dx.doi.org/10.1533/9780857098931.1.108

5. Global Flame Retardant Chemicals Market Outlook (2014-2022), Stratistics MRC, 19.08. 2015 [online]. [Viewed 10 February 2015]. Available from: http://www.reportlinker.com/p03173516summary/view-report.html.

6. Bernava, A., Strazds, G., The Flame Retardant Coating of Linen Fabrics, Advanced Materials Research, 2015, vol. 1117, pp. 219-222. http://dx.doi.org/10.4028/www.scientific.net/AMR.1117.219

7. Our competence for your success, unique ideas. Unique solutions, CHT Bezema, 2011, pp. 1-80.

Aina Bernava, Linu audumu apdrukāšana degamības samazināšanai

Darba ietvaros pētīta nebalināta linu jēlauduma, balināta linu auduma (ražotājs SIA Larelini, Latvija) degšanas raksturojums pirms un pēc apdrukas. Audumi pirms apdrukāšanas mazgāti Felosan NOF ūdens šḳ̄iumā. Drukas pasta sastāvā ietilpst rūpnieciskā pasta Tubivis DRL 300 vai Tubvinyl $235 \mathrm{MC}$, organisko fosforu saturošais liesmu slāpētājs celulozes šķiedrām Apyrol CEP (ķimikāliju attiecība drukas pastas sastāvā 1:2) un pigments Bezaprint Green BT (2\% no drukas pastas masas). Visi paraugi apdrukāti, izmantojot vienu šablonu, ar sieta apdrukas paṇēmienu (žāvēšana $110-120^{\circ} \mathrm{C}, 7 \pm 1$ min, termiskā apstrāde $160{ }^{\circ} \mathrm{C}, 3 \pm 1$ min). Apdrukāto audumu labajā pusē ir dekoratīvs raksts, bet kreisajā auduma pusē redzama drukas pastas izspiešanās, īpaši pēc apdrukas ar Tubvinyl 235 MC pastu. Pusi apdrukāto audumu mazgāja 5 reizes sodas $3 \mathrm{~g} \cdot 1^{-1}$ un Felosan NOF $5 \mathrm{~g} \cdot 1^{-1}$ ùdens šks̄īumā. Apdrukas kvalitāte pēc mazgāšanas nemainījās. Degšanu raksturojošā pārbaude LVS EN ISO 15025:2003 parādīja, ka jēlaudums un balinātais linu audums sadeg pilnīgi un degšanas laikā veidojas pelni. Ar Tubivis DRL 300 apdrukāts balinātais linu audums nedega un kvēlošanas laiks bija 40-29 reizes īsāks nekā audumiem bez apdrukas. Ar Tubvinyl 235 MC apdrukātie balinātie linu audumi sadega piln̄̄gi, savukārt kvēlošanas laiks bija 4.6-3.9 reizes īsāks nekā neapdrukātajam audumam. Jēlaudumam, apdrukātam ar abiem drukas pastas sastāviem, pēc mazgāšanas uzlabojas īpašības - kvēlošanas laiks ir 1.3-1.9 reizes īsāks nekā pirms mazgāšanas un 2.7-1.8 reizes īsāks nekā linu jēlaudumam bez apdrukas. Visiem apdrukātajiem audumiem sadegot veidojās pelni, izṇemot balināto lina audumu ar Tubivis DRL 300 apdruku.

\section{Айна Бернава. Покрытие льняного полотна для снижения горючести}

К настоящем исследовании рассмотрено покрытие суровой и отбеленной, предварительно выстиранной льняной (100\%) ткани (изготовитель “Larelini”" Латвия) сетчатым методом с последовательной сушкой при $110-120{ }^{\circ} \mathrm{C} 7 \pm 1$ мин и тепловой обработкой 160 ${ }^{\circ} \mathrm{C} 3 \pm 1$ мин для снижения горючести полотна. Состав наносимой пасты: промышленная паста Tubivis DRL 300 или Tubvinyl 235 с добавкой огнезащитного вещества для целлюлозы Apyrol CEP (соотношение в наносимой пасте 1: 2), пигмент Веzaprint Green BT (2 \% от массы наносимой пасты). Все образцы были покрыты с помощью одного шаблона. Половина покрытых тканей промывались водным раствором (сода 3г/л и Felosan NOF 5 г/л). После промывки качество покрытых тканей не изменилось. Тест ткани на горючесть (LVS EN ISO 15025:2003) показывает, что суровое и отбёленое льняное полотно сгорает с образованием пепла. Отбелёная ткань, покрытая пастой Tubivis DRL 300, не горит, а время истлевания в 40-29 раз короче, чем у ткани без печати. Пепел не образуется. Отбелёная ткань опечатанная пастой Tubvilyl 235 МС сгорает полностью, но время истлевания - в 4.6-3.9 раз меньше, чем у ткани без обработки. Обработанное обеими пастами суровое полотно после 5 стирок не горит, пламя гасится, и время истлевания в $1.3-1.9$ раз короче, чем у полотна без стирки, и в 2.7-1.8 раз короче, чем у суровой ткани без нанесенного рисунка. Все покрытые и промытые ткани при сгорании образуют пепел, за исключением отбеленной ткани, покрытой пастой Tubivis DRL 300. 